\title{
The Impact of Shopbot Use on Prices and Price Dispersion: Evidence from Online Book Retailing
}

\author{
Zhulei Tang ${ }^{\dagger}$, Alan Montgomery ${ }^{\ddagger}$, Michael D. Smith ${ }^{*}$ \\ zhulei@purdue.edu, \{alm3, mds\}@andrew.cmu.edu,
}

This Version: January, 2007

Acknowledgements: The authors thank Christopher Muenchhoff of Dealtime.com and MediaMetrix for generously providing data for use in this research. The authors thank participants at the 2005 Workshop on Information Systems and Economics for valuable comments on the research. Smith thanks the National Science Foundation for generous financial support provided through CAREER award IIS-0118767.

$\dagger^{\dagger}$ Krannert School of Management, Purdue University, West Lafayette, IN 47907. (765-4944505)

‡ Tepper School of Business, Carnegie Mellon University, Pittsburgh, PA 15213. (412-2684562)

* H. John Heinz III School of Public Policy and Management, Carnegie Mellon University, Pittsburgh, PA 15213. (412-268-5978) 


\title{
The Impact of Shopbot Use on Prices and Price Dispersion: Evidence from Online Book Retailing
}

\begin{abstract}
The growth of Internet price search tools, notably shopbots, has reduced consumers' search costs, allowing consumers to easily become informed of price and product characteristics among competing sellers online. While a variety of analytic models predict that increased consumer search through shopbots will lower price levels among competing retailers, there is no consensus in the empirical literature as to whether price dispersion will increase or decrease in response to increased consumer search through shopbots. Moreover, there are no papers that have analyzed this question using direct observation of variation in shopbot use over time.

This paper seeks to examine the impact of changes in shopbot use over time on pricing behavior in the Internet book market. Using price data obtained from a leading shopbot, combined with clickstream data on shopbot usage from August 1999 to July 2001, we show that an increase of $1 \%$ in shopbot use is correlated with a $\$ 0.41$ decrease in price levels, after controlling for book characteristics and the market competition condition. We also show that price dispersion decreases with shopbot use nonlinearly. This relationship is robust when we control for potential simultaneity bias and the possible influence of prominent retailers, bestsellers, holiday effect, and online book industry structural changes.
\end{abstract}

Keywords: Search Cost; Shopbot; Clickstream; Internet; Price Dispersion 


\section{Introduction}

Shopbots are software intelligent agents that automatically query multiple on-line vendors to gather information about prices and other attributes of products at a given point in time, and usually make the information free to the consumers (Smith 2002). In this way, shopbots act as a central "clearinghouse”, where firms and consumers gather to transmit and acquire information (Baye and Morgan 2001). Consumers can typically purchase by clicking one of the hyperlinks on a shopbot's page to be directed to individual stores.

Shopbots greatly reduce search costs for consumers. While a variety of analytic models predict that increased shopbot use will lead to decreased price levels among retailers, there is no consensus in the literature as to whether increased shopbot use will decrease price dispersion (through increased competition among firms) or increase price dispersion (through increased use of mixed strategy pricing). Moreover, due to data limitations there have been very few papers that have analyzed this question empirically, ${ }^{1}$ and none that we are aware of that use direct observation of variation in shopbot use over time.

This research seeks to fill this gap in the literature by analyzing the impact of changes in shopbot use over time on the pricing behavior in the Internet book market. By combining price data obtained from an Internet shopbot with clickstream data on shopbot usage from August 1999 to July 2001, we are able to show how reduced search cost influences online book retailers’ pricing behavior, and therefore, the market competition.

\footnotetext{
${ }^{1}$ Notable exceptions include Sorensen (2000) with regard to search intensity for pharmaceuticals, Brown and Goolsbee (2002) with regard to the introduction of Internet for term life insurance, and Baye, Morgan, and Scholten (2004a) with regard to the influence of the number of firms on price dispersion.
} 
We study books - well-defined homogenous goods, with low marginal cost, in a relatively mature Internet market (Smith 2000). Books can be identified by their ISBNs and they have limited but easily comparable features. Most factors that may influence the purchase of a book can be associated with prices and can be easily quantified. Our book search data were collected from Dealtime.com, one of the most popular Internet shopbots for books during our study period. The data set contains information with regard to the total price of books (and the elements of the prices) and the characteristics of the books.

We compute the shopbot usage measure from a clickstream dataset collected through Media Metrix's PC Meter. Clickstream data refer to the sequence of WWW URLs or pages visited and the time these pages were viewed. We have individual level clickstream data recorded daily during a five-year period from July 1997 through May 2002, from which we can calculate several measures of shopbot usage, for example, the percentage of people who use a shopbot and the percentage of people who use a book shopbot, with the latter more specific to book shoppers. We then map the shopbot usage data with our Dealtime data according to the time that a search occurred and examine the possible impact of search behavior on book prices.

The results show that after controlling for book characteristics and the market competition condition, an increase in shopbot use of $1 \%$ results in a $\$ 0.41$ decrease in price levels. We also find that price dispersion decreases with shopbot use nonlinearly. Finally, we find that the number of prominent retailers that offer a book negatively influences prices and price dispersion. These results are not driven by the pricing strategies of prominent retailers, bestseller discount, holiday effect, and possible structural changes of online book industry. These results shed light on the dynamics 
between consumer search behavior and retailer pricing strategies and provide empirical confirmation for the predictions of several analytic models.

The rest of the paper is organized as the following. In Section 2, we review the relevant literature. In Section 3, we state our hypotheses. In Section 4, we describe the data. In

Section 5, we show the empirical results. In Section 6 we consider alternative explanations of the results. Section 7 concludes with discussion and future directions.

\section{Literature Review}

Our work follows the economics literature on the impact of search on prices and price dispersion. Following Stigler (1961), several analytical papers have examined the impact of search costs and asymmetric information on equilibrium prices and price dispersion. A common assumption in this literature is that some consumers do not know the price distribution, while other consumers do. Under this assumption, equilibrium price dispersion can arise in a homogenous goods market with symmetric firms. Notable papers in this literature include Varian (1980), which finds equilibrium price dispersion in the context of sales: stores randomize prices in an attempt to price discriminate between informed and uninformed consumers. Stahl (1989) “endogenizes" the consumers' decision to be informed or uninformed by assuming that some consumers have positive search costs, while others have zero search costs. Under a sequential search game, price dispersion arises as an equilibrium outcome. The comparative statics are informative to the current research. It shows the relationship between prices and price dispersion and the parameters of the model: the proportion of informed consumers and the search cost. We expand on these comparative statics in Section 3. 
Chen and Hitt (2004) incorporate two sources of price dispersion, limited awareness and brand sensitivity, to address the inconsistencies between the predictions of the search literature and the empirical findings in the Internet market. They find that average prices in the market are reduced as consumers become better informed. They also find that price dispersion may increase before most consumers are informed about prices. The search theory provides theoretical guidance for our empirical findings.

Sorensen (2000) establishes the empirical importance of price dispersion due to costly consumer search. By examining local retail prices for prescription drugs, he finds that prices for repeatedly purchased prescriptions (for which the benefits of search are highest) exhibit significant reductions in both dispersion and price-cost margins.

In the context of the Internet, Baye and Morgan (2001) examine the equilibrium interaction between a market for price information controlled by a gatekeeper (e.g., shopbot) and the homogenous product market it serves. They show that the gatekeeper's profit is maximized in equilibrium where the product market exhibits price dispersion. Iyer and Pazgal (2003) also analyze the effect of shopbots on retail competition. Their focus is on the Internet retailers' decision of whether to join shopbots. The results indicate that the prices charged by inside retailers can vary substantially. The average prices charged by inside retailers can increase or decrease when more retailers join, depending on whether or not the reach of the shopbot is independent of the number of joining retailers.

Our paper builds on the search literature by conceptualizing consumers who use shopbots as informed consumers, and consumers who do not use shopbots as uninformed 
consumers. Informed consumers incur a cost to visit shopbots and learn the price distribution. Uninformed consumers only visit an individual seller's website, and therefore do not know the whole price distribution. Similar conceptualization has been used by Brown and Goolsbee (2002) in studying the impact of the introduction of Internet on term life insurance prices.

Despite the extensive literature on search theory, there have been relatively few empirical studies of price and price dispersion in the online markets. Notable exceptions include Brynjolfsson and Smith (2000), who find that while prices on the Internet are lower than prices in conventional outlets, price dispersion is higher on the Internet than in conventional outlets. Baye, Morgan, and Scholten (2004a) examine price dispersion of multiple products on a price comparison site. They find that price dispersion is greater when a small number of firms list prices than when a large number of firms list prices. Baye, Morgan, and Scholten (2004b) find significant variation in the identity of the lowprice firms as well as the level of the lowest price for best-selling consumer electronics products sold at a price comparison site. Interestingly, their studies cover similar, although shorter, time period as the current research.

The most relevant empirical literature to our work is Brown and Goolsbee (2002), who study the impact of Internet on the offline life insurance prices and price dispersion. Their findings indicate that rising Internet usage reduces term life insurance prices. Price dispersion increases with the initial introduction of the Internet search sites, but as the share of people using the technology rises further, dispersion falls. 
The current paper differs from Brown and Goolsbee's work in that we are able to directly measure changes in price levels and price dispersion based on observation of variation in shopbot use over time. Our data also differ from much of the extant literature in that our observed products come directly from actual consumer searches as opposed to coming from a "random" sub-sample of books in print as in common in the literature. This use of direct observation of consumer product searches provides us with a more representative sample of books than much of the extant literature.

\section{Theory and Hypotheses}

The central hypothesis of this paper is that since using shopbots reduces search costs and helps consumers discover and compare prices more easily, increased adoption of shopbots should influence retailers' pricing strategy. As discussed above, a variety of search theory models have predicted the impact of search costs on price distribution. The IS literature has also established the existence of price dispersion in the online market. In this section, we will mainly use the predictions from the literature to form our hypotheses.

The search literature usually assumes a homogeneous product market with multiple stores. Some consumers search with zero cost, while others incur a positive search cost $c$. The consumers with positive search cost are relatively uninformed and therefore will buy from the first store with the price below their reservation price. Consumers with zero search cost search all the stores and buy from the store with the lowest price. In equilibrium, stores will charge a price drawn from a distribution (Varian 1980, Stahl 1989). The setting can be easily extrapolated to the Internet book market: Online bookstores compete for book consumers; some consumers visit shopbots to compare 
prices before purchase, while others go to individual book retailers' websites directly to purchase. If we assume the consumers who use shopbots can obtain all price listings and therefore purchase at the lowest price, then the shopbot users will be the zero-search-cost customers. Both the search theory and IS literature predict that when the search cost decreases, prices would become more competitive. Our first hypothesis follows directly from this prediction.

Hypothesis 1. Prices decrease in shopbot use.

Essentially in Hypothesis 1, we use the percentage of consumers who use shopbot as a proxy for informed consumers - the more the informed consumers, the more competitive the market is, therefore retailers need to drop prices.

By similar arguments, when more consumers search, retailers are more likely to engage in price competition, undermining their profitability. In fact the search theory literature predicts that products for which consumers are more likely to compare prices should have lower price-cost margins (Sorensen 2000). Therefore, we should expect that price margin is negatively related to shopbot use. Thus we have the following hypothesis:

Hypothesis 2. Price-cost margins decrease in shopbot use.

Our next hypothesis is with regard to price dispersion. It has been established in the IS and economic literatures that, although the Internet may lower consumer search costs, price dispersion still exists (e.g., Brynjolfsson and Smith 2000, Clay, Krishnan, and Wolff 2001). This is reasonable as, on one hand, when more consumers use shopbots to search products and compare offerings, the competition among retailers drives their prices toward the competitive price, therefore price dispersion may decrease. While, on the other hand, because retailers face a less profit margin overall, they will try to exploit 
more profit from uninformed consumers by charging higher prices to uninformed consumers, which will increase price dispersion. Thus price dispersion can either increase or decrease in the presence of lower search costs or increased search intensity.

The above analysis is also consistent with what is predicted in the search theory literature, which finds that when the proportion of zero-search-cost customers approaches to zero, the Nash Equilibrium price distribution converges to the monopoly price; when the proportion of zero-search-cost customers approaches to one, the price distribution converges to the competitive price (Stahl 1989). This implies that price dispersion changes non-monotonically with the proportion of the informed customers. Therefore, we expect:

Hypothesis 3. Price dispersion is non-monotonic in shopbot use.

Not only does price dispersion vary with buyer search costs, but it also varies with market structure, for example, competition. The online bookselling market is highly concentrated, with Amazon.com representing approximately 70\% of total market share (Ehrens and Markus 2000). Together with BarnesandNoble.com and Borders.com, the big three retailers (Big 3) dominate the online bookselling market. In our data, more than $98.3 \%$ of the search results contain at least an offer made by the top three retailers. Due to the concentration, the top three retailers may serve as a focal point for consumer search. Because of this, “Big 3” retailers may attempt to undercut each other’s prices, which will intensify competition, leading to lower prices and lower price dipsersion. Thus, we formulate the following two hypotheses as:

Нyротнesis 4. When more Big 3 retailers list their prices, prices decrease.

Hypothesis 5. When more Big 3 retailers list their prices, price dispersion decreases. 


\section{Data}

To analyze the relationship between the shopbot use and price and price dispersion, we take individual search-level data from Dealtime.com on the prices of books as well as various book characteristics and market competition conditions and match this data to data on the growth of shopbot use as tracked by clickstream data obtained by MediaMetrix. We then fit a hedonic regression for the price levels and price dispersion of books on how likely consumers conduct a search using shopbots, including characteristics of the books and the market competition conditions.

\section{Data on Book Prices}

The data on book prices come from actual book search by Dealtime.com consumers from August 25, 1999 to July 25, 2001. Dealtime.com is a shopbot that queries up to 60 book retailers and returns price and availability information in a tabular format (Figure 1). We agregate this data into individual sessions, which we define as a search on a specific book identified by an ISBN. Within each session we observe the date and time that the search occurred, the ISBN of a book, the total price and its components (item price, shipping cost, and sales taxes if applicable), and the retailers who carry that book.

We augment the Dealtime data with two additional data sets. The first is book characteristics obtained from Bowker's Books in Print: binding type (hardcover or paperback), book category, and publisher's list price. The second is whether a book was listed on the New York Times bestseller list on the date the prices were provided. 


\section{Data on Shopbot Use}

Our shopbot use measures are computed from a clickstream data set collected through Media Metrix’s PC Meter. The PC Meter is a program that records information about who is using a computer, what applications are running or URLs are being viewed, and how long they are in use. $^{2}$ Clickstream data refers to the sequence of URLs or pages visited and the time these pages were viewed. Media Metrix collects the clickstream data from a nationwide panel of over 20,000 individuals during a five-year period from July 1997 through May 2002.

Media Metrix categorizes websites according to their functions. For the purpose of this research, we compile four categories of website lists according to Media Metrix's definitions: retailing sites, online bookstores, shopbots, and book shopbots. Because the categories defined by Media Metrix do not match our lists exactly, we compile our lists by taking the broadest definition. That is, if Media Metrix defines different categories of shopbots, we include all of these categories in our list of shopbots. Because Media Metrix revises their definitions of categories during our analysis period, in case a conflict occurs in their early and later definitions, we take the most recent one as we compile our lists.

We define book shopbots and general purpose shopbots in the following way. All book shopbots $^{3}$ list books as one of their major search categories. In contrast, general purpose shopbots do not feature book price search per se, instead these shopbots typically focus on broader search categories such as, gifts and travel. Frequently, people can still search for books by using a general purpose shopbots. However, the key word "Books" is most

\footnotetext{
${ }^{2}$ For a detailed discussion on Clickstream data, see Montgomery (1999).

${ }^{3}$ Shopbots, such as, Dealtime.com, Bottomdollar.com, Pricescan.com, and MySimon.com are categorized as book shopbots.
} 
often put in a less important position, sometimes, not directly observable from a main page. We define retailing sites and online bookstores in the following way. Retailing sites are mainly online shopping sites; while online bookstores include book retailers' web sites, such as BarnesandNoble.com. They also include publishers' sites, such as www.bottomlinesecrets.com (for Bottom Line Publications) and book clubs sites, such as www.bomc.com (for Book-of-the-Month Club).

We use these data to compute two measures of shopbot use. The proportion of people who use shopbots in a given month is computed by dividing the percentage of people who use a shopbot by the percentage of people who visit a retailing site in a given month; The proportion of people who use a book shopbot is computed by dividing the percentage of people who use a book shopbot by the percentage of people who visit an online bookstore in a given month. Each percentage is computed based on whether a user visited any of the domains associated with one of the four categories during a month. Essentially the first measure is the shopbot usage of general online shoppers and the second measure is more specific to book shoppers. The time period covered by the data, August 1999 to July 2001, is a particularly important time period as the Media Metrix data show a dramatic increase in shopbot use from 7.2\% in August 1999 to 16.3\% in July 2001 and an increase in book shopbot use from $11.9 \%$ to $25.4 \%$ during the same period (Figure 2).

The dataset contains prices and price dispersion measures for 75,765 searches conducted by U.S.-based customers. ${ }^{4}$ Key summary statistics are provided in Table 1 . The data show a significant dispersion in prices. $14.8 \%$ of the sessions have a difference between the highest and lowest offers exceeding the list price. $65.5 \%$ of sessions have the

\footnotetext{
${ }^{4}$ We eliminate international searches because our shopbot measure is constructed for U.S. consumers.
} 
difference exceeding $\$ 10$. The average difference between the maximum item price and minimum item price per session is $\$ 19.1$ which corresponds to $57.2 \%$ of the average item price per session. The number of retailers offering a book also varies from a minimum of 2 retailers to a maximum of 21 retailers, with an average of 11 retailers offering a book. Almost always the Big 3 retailers offer a book being searched. 98.3\% of the search results contain at least an offer made by the Big 3 retailers. $56.5 \%$ of the time all the top three retailers make an offer.

\section{Basic Model and Results}

\subsection{Price Levels}

Our main interest is on the proportion of book shoppers who use book shopbots as defined above. ${ }^{5}$ The following variables are included to control for their influences on prices. Wholesale price is included to control for the cost that may attribute to different prices. We calculate the wholesale price of the book as $53 \%$ of the list price following the prior literature (Brynjolfsson, Hu, and Smith 2003) and thus this variable can also be interpreted as a scaled version of list price. We include control variables for the book type including the genre of the book (CATID), its binding type — paperback, hardcover (HC), or other media (OTHERMED). We also include a dummy variable indicating whether the book was on the New York Times bestseller list at the time the price quotes were provided. This controls for the fact that New York Times bestsellers are typically offered at significant discounts and may have different competitive dynamics than other titles do. Finally, we include two variables to count for the competition coming from the Big 3 online booksellers (NUMBIG3) and from the other retailers as well (NUMPR).

\footnotetext{
${ }^{5}$ The results are similar if we use the proportion of shoppers who use shopbots.
} 
The price level regression is specified as follows:

Avg Price $_{s}=\alpha_{0}+\alpha_{1}$ ShopbotUse $_{s}+\alpha_{2}$ Wholesale Price $_{s}+\alpha_{3} N Y T_{s}+\alpha_{4}$ NUMBIG $_{s}+\sum_{l=1}^{10} \alpha_{l+4} C A T_{l s}$ $+\alpha_{15} N_{U M P R_{s}}+\alpha_{16} \mathrm{OTHERMED}_{\mathrm{s}}+\alpha_{17} H \mathrm{C}_{\mathrm{s}}+\varepsilon_{\mathrm{s}}$

The subscript $s$ identifies unique sessions. To ensure the model is robust to symmetric non-normality in the disturbances we computed Huber/White/sandwich estimator of variance for the coefficient estimates (Huber 1967, White 1980).

The results are shown in column 1 of Table 2. As noted above, both the search theory and IS literature uniformly suggests that prices should fall with increased shopbot use. The results confirm this prediction. The coefficient on shopbot use is negative and statistically significant, suggesting that an increase in shopbot use is associated with a drop in prices. In particular, when shopbot use increases 1 percent, prices fall \$0.41. Therefore, we accept Hypothesis 1. Without surprise, when the wholesale price increases, prices also increase.

Most of the signs on the control variables in this regression are consistent with expectations. Participation of the big 3 retailers has a negative impact on the price. When the number of Big 3 retailers offering a book increases 1, the average price falls about \$2.30. Thus Hypothesis 4 is supported. Prices also go down as more other competing retailers offer the same book. The competition from the Big 3 retailers has a much larger impact on prices than competition from other retailers did. If a book is in a binding format other than paperback or hardcover, for example a CD-ROM, prices are lower, thought the coefficient is statistically insignificant. Interestingly, average prices for New 
York Times bestsellers are not lower than other books. This result seemingly contradicts the traditional view that retailers often offer large discount to New York Times bestsellers. To further investigate the problem, we run (1) according to different book categories. We find that for some categories of books, such as art books, New York Times bestsellers do have lower average prices. However, for other categories of books, such as religion books, New York Times bestsellers do not have lower prices. In the sample, more books fall into the latter categories. Subsequent analysis in Section 6 shows that the Big 3 retailers do discount NYT bestsellers and charge lower prices, but the smaller retailers do not follow this strategy.

In the second column of Table 2, we add two yearly dummies to control for the fact that prices may drop over time. Coefficients on the two dummies clearly indicate this trend. However, book shopbot use still has a negative impact on the prices, with the magnitude of the rest of the coefficients varying very slightly.

\subsection{Price Margins}

To examine Hypothesis 2, we use similar specification as in the price level regression. Price margin is calculated by subtracting the wholesale price from the item price. As noted above, we use the wholesale price as a proxy for the cost of the online book retailers and it is shown to be accurate (Brynjolfsson, Hu, and Smith 2003). Column 3 of Table 2 shows the results. The results indicate that price margin falls $\$ 0.27$ with an increase in shopbot use of 1 percent. Thus, Hypothesis 2 is supported. Also note that competition leads to decreased price-cost margin. When more of the Big 3 retailers offer the product, the margin falls. This is also true in general when more retailers offer the 
same book. The impact of the former on price-cost margin far exceeds that of the latter, indicating the dominance of the Big 3 retailers on the online bookselling market. Perhaps the lower price margin of the Big 3 retailers can be compensated through larger sales volumes.

\subsection{Price Dispersion}

The results of price dispersion are summarized in Table 3. We start by using the standard deviation of price per session as the measure for price dispersion. The square of the shopbot use measure is included to allow for possible nonlinearity. Column 1 of Table 3 reports the result. Among all the variables that explain price dispersion, the shopbot use variable provides the highest explanatory power. The significance of the coefficient of the shopbot use and the coefficient of the square of shopbot use point to the fact that the impact of shopbot use on price dispersion is nonlinear. The plot of estimated price dispersion against the shopbot use (Figure 3) shows that price dispersion decreases with shopbot use nonlinearly. The general decreasing trend is accompanied by small fluctuations.

The most natural explanation for the observed relationship between shopbot use and price dispersion is that when more people search, the increased awareness of prices intensifies competition, which leads to the falling price dispersion. This explanation seems to apply to most of the data. However in the long run this pricing strategy might not last, because it damages the profitability of the retailers. Some retailers may deviate from "the law of one price” by experimenting with other pricing strategies. Therefore we observe the small fluctuations along the general decreasing trend. Thus Hypothesis 3 is not supported. 
The results also indicate that when there are more Big 3 retailers offering a book, price dispersion decreases. The competition among the top retailers tends to decrease the price difference. The evidence supports Hypothesis 5. The same is not true for all retailers. When more retailers sell a book, price dispersion increases. One explanation for this is that smaller retailers tend not to engage in price competition. They may make profit using a variety of strategies, for example, by charging relatively higher prices for some books and lower prices for other books. Including more "smaller" retailers introduces more diverse prices. Together with the observed nonlinearity, the different pricing strategies of the Big 3 retailers and the smaller retailers may reveal that initially when the percentage of people who use shopbot increases, the smaller retailers follow the big retailers pricing strategies closely to lower prices. Therefore price dispersion falls. However, for the smaller retailers, when the percentage of people who use shopbot continues to increase, unlike the big retailers, the lost profit cannot be compensated by the sales volume. At this point, the smaller retailers have to begin experiments with other pricing and non-pricing strategies. Therefore, occasionally we observe increased price dispersion.

We use several alternative measures of price dispersion from the literature to test the robustness of the above results. Our results are shown in Column 2-5 of Table 3. Column 2 lists the results using range, which is the difference between the highest and the lowest prices. Column 3 uses the difference between the average and minimum price as the dispersion measure. Column 4 uses the ratio between the range and the minimum price as the dispersion measure. Column 5 uses the difference between the two lowest prices as the dispersion measure. Different measures capture the underlining price distribution differently. For example, unlike the other measures which all reflect the whole price 
distribution to some extent, the difference between the lowest two prices assigns more weight to low prices. If consumers who use shopbot to search are more price sensitive, lower prices will generate more sales than higher prices. Therefore, this measure can be seen as a quantity-weighted measure of price dispersion (Baye, Morgan, and Scholten 2004a).

The results with respect to the book shopbot use and the competition from the top retailers are robust across price dispersion measures: when the proportion of consumers who use book shopbot increases, price dispersion decreases nonlinearly; when more Big 3 retailers sell a book, price dispersion falls. These findings are against Hypothesis 3. Nonetheless Hypothesis 5 is supported.

For most of the measures, price dispersion increases as more retailers offer the book, with the exception when we use the difference between the lowest two prices as the measure. Since this measure tends to weigh low prices more, the result indicates that perhaps retailers who usually charge lower prices are more actively engaged in price competition, so when more retailers provide the same book, the low price retailers compete by undercutting each others' prices until the price gap shrinks. Overall, retailers seem to take different strategies. They either engage in price competition by charging lower prices or try to compensate small sales volumes by occasionally charging higher prices.

\section{Alternative Explanations}

While our results may indicate that an increase in shopbot use leads to decreased prices and price dispersion, there are a variety of alternative explanations that could indicate 
spurious correlation or reverse causality. We explore these alternative explanations in this section.

\subsection{Pricing Strategies of Prominent Retailers}

One potential alternative explanation is that during our analysis period, prominent retailers, such as Amazonc.om, BarnesandNoble.com, and Borders.com, may have changed their pricing strategies and that these price changes - not changes in shopbot use — influence price levels and price dispersion.

A direct test of this hypothesis is to exclude the Big 3 retailers from the sample. We run the same price and price dispersion regression excluding data from the Big 3 retailers. ${ }^{6}$ The results are shown in column 1 and 2 of Table 4 . The coefficients still show the same effect of shopbot use and competition on price and price dispersion, with all the other coefficients having the same signs as before. Thus, our findings seem to be robust to changes in Big 3 pricing.

As a further test, we also run the same regression including only data from the Big 3 retailers. The results are shown in the last two columns of Table 4. The average prices and price dispersion both decrease with book shopbot use, but with smaller magnitude than those in the full sample. This result is intuitive - though the use of search tools drives down the prices and price dispersion of the Big 3 retailers, these retailers have a disproportionate number of "loyal" customers and are not influenced by these changes as much as the smaller retailers are.

\footnotetext{
${ }^{6}$ From now on, we use standard deviation of prices in the price dispersion regression. Results are similar if we use other measures of price dispersion.
} 
We also note that the Big 3 retailers charge lower prices for NYT bestsellers than other retailers do. While the Big 3 retailers only offer slightly deeper discount in general (9.1\%), they offer much higher discount for the NYT bestsellers (26.6\%). Next, we examine the possible impact of the NYT bestsellers on the retailers pricing strategies.

\subsection{Bestseller Discount}

Another alternative explanation for our results is that the pattern of price level and price dispersion we observe may be driven by the prices of New York Times (NYT) bestsellers, because NYT bestsellers represent high aggregate sales and are a focal point for discounts (Clay, Krishnan, and Wolff 2001). As a general check of this explanation, we note that the average discount off list price for all the books in our sample is $8.3 \%$, while the average discount for NYT bestsellers is only slightly larger at $10.8 \%$. Further, only about $9 \%$ of our sample comes from bestsellers. ${ }^{7}$ Given these facts, the magnitude of the influence of NYT bestsellers on our results is likely to be small.

As a formal test, we remove NYT bestsellers from the sample and run the same regressions. The results are shown in column 1 and 2 of Table 5 . The results continue to show that price and price dispersion decrease with shopbot use. Although removing bestsellers makes the price drop less dramatic, price level still decreases and the change is statistically significant. The coefficient on shopbot use in the price dispersion regression, however, is larger in magnitude without the NYT bestsellers: -5.4 versus -4.8 for the first order effect and 8.4 versus 7.3 for the second order effect. It is interesting to see that

\footnotetext{
${ }^{7} 9,405$ out of a total of 106,467 titles.
} 
online booksellers do not set similar prices for NYT bestsellers — by removing the bestsellers, price dispersion drops even more when shopbot use increases.

\subsection{Holiday Effect}

It could be argued that during the end-of-year holiday season online booksellers offer larger discounts to promote sales, which leads to decreased prices and price dispersion. This could influence our results if simultaneously holiday shoppers are more likely to use shopbots for comparison shopping. As a straightforward check, the trend of monthly average prices, price dispersion, and shopbot use in Figure 2 and Figure 4 does not seem to support this argument — while shopbot use increases during the holiday season, average price and price dispersion do not always decrease during the same period of time.

To analyze this alternative explanation further, we remove all observations from December and run the same regressions as in the basic model. The results are shown in column 3 and 4 of Table 5. The coefficients still show the same effect of shopbot use and, if anything, are larger than before in the price regression: the coefficient on shopbot use is -43.4, compared with -41.3 before. In the dispersion regression the coefficients on shopbot use are similar: -4.7 versus -4.8 before for the first order effect and 7.4 versus 7.3 for the second order effect. Meanwhile the number of Big3 retailers that sell a book still has a negative impact on the average price and price dispersion. Therefore the results do not seem to be driven by the holiday discount.

\subsection{Structural Changes in the Online Book Market}

One potential structural change in the book market during our time period is the number of firms operating in the market. Prior research has used the number of firms posting 
prices at the shopbot as a proxy for overall market competition (Baye, Morgan and Scholten 2004a, Clay, Krishnan, and Wolff 2001). In the regressions we include two variables to control for the structural changes in the online book market. One is the number of retailers that list prices. This variable can be seen as reflecting the overall market competition. Because of the high concentration of the online book retailing, we also include another variable the number of Big 3 retailers that list prices to control for the impact of the prominent sellers on prices and price dispersion. We have seen that “Big 3" retailers may play a more important role in influencing the prices and price dispersion than other retailer do. The difference between the two coefficients may be due to the different pricing strategies between the Big 3 retailers and smaller retailers.

The second source of structural change can be the change of the degree of concentration of the online book market. As has been widely observed, the Internet book market is heavily concentrated, with Amazon.com commanding more than $70 \%$ of the total market share (Ehrens and Markus 2000) and BarnesandNoble.com and Borders.com representing a large fraction of the remaining market. However, we observe insignificant changes in the concentration during our study period. Moreover, we have shown in Section 6.1 that our results persist even if "Big 3" prices are removed. To the extent that the degree of concentration of the online book retailing market is largely determined by the Big 3 retailers, removing them will rule out the price change directly brought by the Big 3 retailers.

The third possible structural change could relate to systematic changes in wholesale prices. For this, we refer to Ghose, Smith, and Telang (2005), which has pointed out that book industry wholesale prices are set as a fraction of list prices and this fraction has not 
changed in recent years. We have also included wholesale prices in the price regression to control for its influence on price change.

\subsection{Book Industry and Macroeconomic Factors}

From the book industry's perspective, book prices may drop if demand decreases. However, neither domestic consumer expenditures on books nor publishers' sales in terms of dollars and units vary significantly during this period. Domestic consumer expenditures on books went from $\$ 10.8$ billion dollars in 1999 to $\$ 11.1$ billion dollars in 2001. Similarly, publishers’ sales went from $\$ 23.8$ billion dollars in 1999 to $\$ 24.6$ billion dollars in 2001 (Book Industry Trend 2003).

From the perspective of the economy as a whole, macro-economic factors, such as inflation, may also influence prices. To test for this, use monthly CPI as the deflator to compute book prices in real dollars and run our price regressions using the CPI adjusted prices. $^{8}$ The results are shown in column 5 of Table 5 . We note that all the coefficients have the same sign as in the regression using raw prices. In particular, the coefficient on shopbot use is -40.7 versus -41.3 before. Thus, although adjusting for inflation lowers the impact of shopbot use slightly, it does not change the results overall.

\subsection{All Effects}

Finally, we consider all of the alternative explanations together. We do this by excluding prices from bestsellers, prices quoted from Big 3 retailers, and prices from the holiday season, and then adjusting the prices to the real prices. The results are shown in Table 6.

\footnotetext{
${ }^{8}$ We only test for the impact of inflation on price levels since price dispersion is not influenced by the use of nominal or real prices.
} 
In the price regression, the coefficient of shopbot use is still negative and significant. In the price dispersion regression, shopbot use has a larger impact on price dispersion once all effects are considered and the signs on the coefficients are the same as before. Thus, considering all the alternative explanations simultaneously, the basic results we find in Section 5 still hold.

\subsection{Time Trend and Lagged Effect}

We have shown that increased shopbot use on the part of consumers is correlated with reduced price levels and reduced price dispersion in the same time period. However, we also note that the relationship between shopbot use and prices may merely due to a time trend: shopbot use increases over time and prices and price dispersion decrease over time. If this is true, we cannot claim a causal relationship between shopbot use and prices.

To deal with these issues, we need to consider the lagged effect of shopbot use on prices and price dispersion and to remove the time trend in the series. Autoregressive Distributed Lags model (ADL) (Hanssens and Liu 1983) helps to deal with both issues. To use the ADL model, we first need to identify the appropriate number of lags to include in the price and price dispersion regressions and to remove the time trend on the shopbot usage time series. ${ }^{9}$

The ADL model includes lagged endogenous and exogenous variables to examine how the exogenous variables affects the time path of the endogenous variable. In the context of our model, the exogenous variable is shopbot usage and the endogenous variable is

\footnotetext{
${ }^{9}$ Note that including lagged shopbot usage variables will also capture any factors that would cause changes in shopbot usage to have a delayed impact on price levels and price dispersion (e.g., the impact of disposable income on consumption, and R\&D investment on profitability).
} 
price or price dispersion. This technique has been used in a variety of setting including the influence of the use of fluorocarbons on the ozone layer (Enders 2004).

A typical ADL model has the following form:

$y_{t}=a_{0}+A(L) y_{t-1}+C(L) z_{t}+B(L) \varepsilon_{t}$

where $z_{t}$ is the exogenous variable, $y_{t}$ is the endogenous variable, and $\varepsilon_{t}$ is a white-noise disturbance. $A(L), B(L)$, and $C(L)$ are polynomials in the lag operator $L$. The goal is to estimate the parameter $a_{0}$ and the parameters of the polynomial $A(L), B(L)$, and $C(L)$. ADL models assume that $\left\{z_{t}\right\}$ is an exogenous process that evolves independently of the $\left\{y_{t}\right\}$ sequence, such that $E z_{t} \varepsilon_{t-s}=0$ for all values of $s$ and $t$. Since $z_{t}$ can be observed, and is uncorrelated with the disturbance term $\varepsilon_{t}$, the current and lagged values of $z_{t}$ can be used as explanatory variables for $y_{t}$.

To employ this model, we first use the exogenous (shopbot usage) and endogenous (price) variables in the ADL model to determine how many lags of shopbot use should be included in the price and price dispersion regressions. In doing so, price levels and price dispersion are transformed in a monthly level to match the monthly shopbot use variable. The augmented Dickey-Fuller test on shopbot usage, prices, and price dispersion indicates that the shopbot use series is non-stationary while prices and price dispersion are stationary. Therefore, we take the first difference of the shopbot use series to eliminate its trend. 
We then follow the procedures specified by Enders (2004) to identify the correct number of lags for the exogenous, endogenous variables, and the error term in (2). The price regression takes the following form:

Avg Price ${ }_{t}=a_{0}+a_{1} \Delta$ ShopbotUse $_{t}$

where the subscript $t$ indicates months. We then use the result of (3) and include the lagged shopbot use after detrending in the basic price regression model (1):

Avg Price s $_{s}=\alpha_{0}+\alpha_{1}$ ShopbotUse $_{t}+\alpha_{2} \Delta$ ShopbotUse $_{t}+\alpha_{3}$ NYT $_{s}+\alpha_{4}$ NUMBIG3 $_{s}$ $+\sum_{l=1}^{10} \alpha_{l+4} C A T_{l s}+\alpha_{15} N U M P R_{s}+\alpha_{16}$ OTHERMED $D_{s}+\alpha_{17} H C_{s}+\varepsilon_{s}$

where the subscript $t$ indicates months and $s$ indicates sessions.

A similar procedure is used to determine the lag structure in the price dispersion regression. The results of both regressions are shown in Table 7 . The results show that prices decrease with an increase in shopbot use, even after controlling for the upward trend of the shopbot use. Increasing shopbot use by 1 percent decreases the price level by approximately $\$ 0.45$. Price dispersion decreases with the increase of shopbot use nonlinearly, even after controlling for the time trend and lagged effect of shopbot use. The coefficients on shopbot use are similar to the ones in the basic results. Interestingly shopbot use not only influences price dispersion directly through a simultaneous effect, but also indirectly through the lagged effect. This lagged effect may reflect the amount of time retailers take to identify the increased search and adjust their pricing strategies. 


\section{Conclusions and Future Research}

The impact of increased consumer search in Internet markets has been a subject of much debate in the literature. While there have been a variety analytic models that have made predictions about the impact of increased shopbot use, there have been far fewer empirical studies of the impact of shopbot use on retailers prices - and none that have used direct observation of changes in shopbot use over time.

To overcome this problem, we combine two datasets. One documenting price levels and price dispersion for a representative sample of books that consumers have searched for,

and second using clickstream data documenting shopbot usage levels by a representative panel of consumes. Our results show that as shopbot usage increases prices decrease and price dispersion decreases nonlinearly. We also show that as more prominent online book sellers offer a book, prices and price dispersion fall. Overall our results suggest that the increased use of shopbots empowers consumers and intensifies the competition of the online book retailing.

These relationships are robust to including different measures of price dispersion and the possible influence of prominent retailers, bestsellers, holiday effect and certain industrywide as well as macroeconomic factors. These results are also robust to including lagged effect of shopbot use on prices and price dispersion to control for possible simultaneity bias. The results the change of shopbot use and the change of the prices and price dispersion may reflect the amount of time retailers take to adjust their pricing strategies.

Our findings are largely consistent with the prediction of the extant search theory literature. The research falls into a broader line of literature documenting the relationship 
between intensified search and market competitiveness. Future research could study consumer search behavior in greater details, for example, by using daily level search data. As the use of Internet search tools become prominent, similar techniques can be applied to the study of other product markets, where other features in addition to prices matter for competition. 


\section{Bibliography}

Baye, M. and Morgan, J. 2001. Information Gatekeepers on the Internet and the Competitiveness of Homogeneous Product Markets. The American Economic Review, 91(3): 454-474.

Baye, M. and Morgan, J, and Scholten, P. 2004a. Price Dispersion in the Small and in the Large: Evidence from an Internet Price Comparison Site. Journal of Industrial Economics, 52 (4): 463-496.

Baye, M. and Morgan, J, and Scholten, P. 2004b. Temporal Price Dispersion: Evidence from an Online Consumer Electronics Market. Journal of Interactive Marketing,18(4): 101-115.

Book Industry Study Group. 2004. Book Industry Trends. Book Industry Study Group, New York, NY.

Brynjolfsson, E., Y. Hu, M. Smith. 2003. Consumer Surplus in the Digital Economy: Estimating the Value of Increased Product Variety. Management Science, 49(11): 15801596.

Brynjolfsson, E. and Smith, M.D. 2000. Frictionless Commerce? A Comparison of Internet and Conventional Retailers. Management Science, 46(4): 563-585.

Brown, J. and Goolsbee, A. 2002. Does the Internet Make Markets More Competitive? Evidence from the Life Insurance Industry. Journal of Political Economy, 110 (3): 481507.

Chen, P. and Hitt, L.M. 2004. A Model of Price Dispersion in Internet-Enabled Markets. Working Paper, Carnegie Mellon University, Pittsburgh, PA.

Clay, K. B., Krishnan, R., and Wolff, E. 2001. Prices and Price Dispersion on the Web: Evidence from the Online Book Industry. Journal of Industrial Economics, 49 (4): 521539.

Ehrens, Scott, Adria Markus. 2000. Amazon.com: There's an "R" in e-tailing. Epoch Partners Consumer Internet Company Report, November 13, 2000, pp. 4.

Enders, W. 2004. Applied Econometric Time Series, 2nd edition. Wiley \& Sons, Inc.

Ghose, Anindya, Michael D. Smith, Rahul Telang. 2006. Internet Exchanges for Used Books: An Empirical Analysis of Product Cannibalization and Welfare Impact. Information Systems Research, 17(1): 3-19.

Greenwald, Amy R., Jeffrey O. Kephart. 1999. Shopbots and Pricebots. Proceedings of the Sixteenth International Joint Conference on Artificial Intelligence, pp. 506-511. 
Hanssens, D.M. and Liu, L. 1983. Lag Specification in Rational Distributed Lag Structural Models. Journal of Business \& Economic Statistics, 1 (4): 316-325.

Huber, P. J. 1967. The Behavior of Maximum Likelihood Estimates Under Nonstandard Conditions. In Proceedings of the Fifth Berkeley Symposium on Mathematical Statistics and Probability. Berkeley, CA: University of California Press, vol. 1, 221-223.

Iyer, G. and Pazgal, A. 2003. Internet Shopping Agents: Virtual Co-Location and Competition. Marketing Science, 22 (1): 85-106.

Kephart, J. O. and Greenwald, A. R. Shopbot Economics. 1999. Proceedings of the Third International Conference on Autonomous Agents (Agents'99), Seattle, Washington, May 1-5, 1999.

Montgomery, A. L. 1999. Using Clickstream Data to Predict WWW Usage, GSIA Working Paper, Carnegie Mellon University, Pittsburgh, PA.

Smith, Michael. 2002. The Impact of Shopbots on Electronic Markets. Journal of the Academy of Marketing Science 30(4) 442-450.

Smith, M.D. 2001. The Law of One Price? The Impact of IT-Enabled Markets on Consumer Search and Retailer Pricing. Working Paper, Carnegie Mellon University, Pittsburgh, PA.

Smith, M.D. 2000. The Great Equalizer? Consumer Choice Behavior at Internet Shopbots. PhD Dissertation, Chapter 2. MIT.

Smith, Michael D., Erik Brynjolfsson. 2001. Customer Decision Making at an Internet Shopbot: Brand Still Matters. The Journal of Industrial Economics, 49 (4): 541-558.

Sorensen, A.T. 2000. Equilibrium Price Dispersion in Retail Markets for Prescription Drugs. The Journal of Political Economy, 108 (4): 833-850.

Stahl, Dale L. 1989. Oligopolistic Pricing with Sequential Consumer Search. The American Economic Review, 79 (4): 700-712.

Stigler, G. 1961. The Economics of Information. Journal of Political Economy, 69(6): 213-225.

Varian, H.R. 1980. A Model of Sales. The American Economic Review, 70(4): 651-659.

White, H. 1980. A Heteroskedasticity-Consistent Covariance Matrix Estimator and a Direct Test for Heteroskedasticity. Econometrica, 48: 817-830. 
Table 1. Summary Statistics August 25, 1999-July 25, 2001

\begin{tabular}{ccccc}
\hline Variable & Mean & S.D. & Min & Max \\
\hline List Price & 33.82 & 34.76 & 1.20 & 994.61 \\
Average Item Price & 32.41 & 35.81 & 1.33 & 995.03 \\
Tax & 0.21 & 1.12 & 0 & 72.43 \\
Shipping Price & 3.62 & 1.48 & 0 & 93.85 \\
\% shopbot usage & 0.16 & 0.03 & 0.07 & 0.25 \\
\% book shopbot usage & 0.25 & 0.04 & 0.11 & 0.36 \\
NYT Bestseller & 0.10 & 0.30 & 0 & 3 \\
Number of Big3 & 2.43 & 0.74 & 0 & 21 \\
No. Retailers per session & 11.02 & 3.83 & 2 & \\
N & 75,765 & & & \\
\hline
\end{tabular}


Table 2. Price Level and Margin

\begin{tabular}{|c|c|c|c|}
\hline & Average Price & Average Price & Price Margin \\
\hline $\begin{array}{l}\text { \%Book Shopbot } \\
\text { Use }\end{array}$ & $\begin{array}{l}-41.347^{*} \\
(2.504)\end{array}$ & $\begin{array}{l}-18.081^{*} \\
(2.719)\end{array}$ & $\begin{array}{c}-26.945^{*} \\
(2.430)\end{array}$ \\
\hline Wholesale price & $\begin{array}{l}1.674^{*} \\
(0.015)\end{array}$ & $\begin{array}{l}1.678^{*} \\
(0.015)\end{array}$ & - \\
\hline Year 00 & - & $\begin{array}{l}-7.084^{*} \\
(0.525)\end{array}$ & - \\
\hline Year 01 & - & $\begin{array}{c}-10.308^{*} \\
(0.499)\end{array}$ & - \\
\hline NYT Bestseller & $\begin{array}{l}2.777^{*} \\
(0.262)\end{array}$ & $\begin{array}{l}2.345^{*} \\
(0.255)\end{array}$ & $\begin{array}{c}0.178 \\
(0.264)\end{array}$ \\
\hline $\begin{array}{l}\text { Number of Big } 3 \\
\text { Retailers }\end{array}$ & $\begin{array}{l}-2.347^{*} \\
(0.116)\end{array}$ & $\begin{array}{l}-3.537^{*} \\
(0.177)\end{array}$ & $\begin{array}{l}-3.175^{*} \\
(0.141)\end{array}$ \\
\hline Number of Retailers & $\begin{array}{l}-0.520^{*} \\
(0.0043)\end{array}$ & $\begin{array}{l}-0.387^{*} \\
(0.025)\end{array}$ & $\begin{array}{l}-0.881^{*} \\
(0.028)\end{array}$ \\
\hline Other binding & $\begin{array}{l}-0.537 \\
(0.354)\end{array}$ & $\begin{array}{l}-0.570 \\
(0.355)\end{array}$ & $\begin{array}{c}3.158^{*} \\
(0.516)\end{array}$ \\
\hline Hardcover & $\begin{array}{l}-0.711^{*} \\
(0.181)\end{array}$ & $\begin{array}{l}-0.916^{*} \\
(0.181)\end{array}$ & $\begin{array}{c}6.311^{*} \\
(0.152)\end{array}$ \\
\hline Dummies & Categories & Categories & Categories \\
\hline Adjusted R-Square & 0.784 & 0.788 & 0.160 \\
\hline $\mathrm{N}$ & 75,765 & 75,765 & 75,765 \\
\hline
\end{tabular}

Note: ${ }^{*}$ significant at $p=0.01$. All category dummies are significant at $p=0.01$. 
Table 3. Price Dispersion Regression

\begin{tabular}{|c|c|c|c|c|c|}
\hline & $\begin{array}{l}\text { Standard } \\
\text { Deviation }\end{array}$ & Range & $\begin{array}{c}\text { Difference } \\
\text { between } \\
\text { Average } \\
\text { and } \\
\text { Minimum } \\
\text { Price } \\
\end{array}$ & $\begin{array}{c}\text { Range } \\
\text { Over } \\
\text { Minimum } \\
\text { Price }\end{array}$ & $\begin{array}{c}\text { Difference } \\
\text { between } \\
\text { Two } \\
\text { Lowest } \\
\text { Price }\end{array}$ \\
\hline \%Book Shopbot Use & $\begin{array}{l}-4.783^{*} \\
(0.138)\end{array}$ & $\begin{array}{c}-626.355^{*} \\
(22.068)\end{array}$ & $\begin{array}{l}-341.382^{*} \\
(14.645)\end{array}$ & $\begin{array}{l}-62.280^{*} \\
(2.233)\end{array}$ & $\begin{array}{l}-290.865^{*} \\
(14.775)\end{array}$ \\
\hline $\begin{array}{l}\text { (\%Book Shopbot } \\
\text { Use) })^{2}\end{array}$ & $\begin{array}{l}7.300^{*} \\
(0.250)\end{array}$ & $\begin{array}{l}979.492^{*} \\
(39.467)\end{array}$ & $\begin{array}{l}527.615^{*} \\
(26.026)\end{array}$ & $\begin{array}{l}92.541^{*} \\
(3.906)\end{array}$ & $\begin{array}{l}448.870^{*} \\
(26.240)\end{array}$ \\
\hline NYT Bestseller & $\begin{array}{c}0.029^{*} \\
(0.002)\end{array}$ & $\begin{array}{l}-1.601^{*} \\
(0.328)\end{array}$ & $\begin{array}{l}-0.359 \\
(0.238)\end{array}$ & $\begin{array}{l}-0.108^{* *} \\
(0.044)\end{array}$ & $\begin{array}{l}0.533^{* *} \\
(0.235)\end{array}$ \\
\hline $\begin{array}{l}\text { Number of Big } 3 \\
\text { Retailers }\end{array}$ & $\begin{array}{l}-0.031^{*} \\
(0.001)\end{array}$ & $\begin{array}{l}-5.052^{*} \\
(0.157)\end{array}$ & $\begin{array}{l}-2.483^{*} \\
(0.103)\end{array}$ & $\begin{array}{l}-0.438^{*} \\
(0.021)\end{array}$ & $\begin{array}{l}-2.054^{*} \\
(0.112)\end{array}$ \\
\hline Number of Retailers & $\begin{array}{c}0.008^{*} \\
(0.000)\end{array}$ & $\begin{array}{c}0.878^{*} \\
(0.030)\end{array}$ & $\begin{array}{c}0.321^{*} \\
(0.020)\end{array}$ & $\begin{array}{l}0.165^{*} \\
(0.004)\end{array}$ & $\begin{array}{l}-0.244^{*} \\
(0.023)\end{array}$ \\
\hline Other binding & $\begin{array}{c}0.004 \\
(0.003)\end{array}$ & $\begin{array}{l}2.745^{*} \\
(0.460)\end{array}$ & $\begin{array}{l}1.242^{*} \\
(0.294)\end{array}$ & $\begin{array}{l}-0.129^{*} \\
(0.052)\end{array}$ & $\begin{array}{c}0.207 \\
(0.291)\end{array}$ \\
\hline Hardcover & $\begin{array}{c}0.006^{*} \\
(0.001)\end{array}$ & $\begin{array}{l}7.724^{*} \\
(0.176)\end{array}$ & $\begin{array}{c}3.330^{*} \\
(0.116)\end{array}$ & $\begin{array}{l}-0.054^{* *} \\
(0.025)\end{array}$ & $\begin{array}{l}1.359^{*} \\
(0.116)\end{array}$ \\
\hline Dummies & Categories & Categories & Categories & Categories & Categories \\
\hline Adjusted R-Square & 0.164 & 0.129 & 0.082 & 0.107 & 0.065 \\
\hline $\mathrm{N}$ & 75,765 & 75,765 & 75,765 & 75,765 & 75,765 \\
\hline
\end{tabular}

Note: ${ }^{*}$ significant at $p=0.01{ }^{* *}$ significant at $p=0.05 .{ }^{* * *}$ significant at $p=0.1$. 
Table 4. Possible Impact of Big 3 Retailers

\begin{tabular}{|c|c|c|c|c|}
\hline & $\begin{array}{c}\text { Average } \\
\text { Price } \\
\text { (Excluding } \\
\text { Big3) }\end{array}$ & $\begin{array}{c}\text { Price } \\
\text { Dispersion } \\
\text { (Excluding } \\
\text { Big3) }\end{array}$ & $\begin{array}{c}\text { Average } \\
\text { Price } \\
\text { (Big3 Only) }\end{array}$ & $\begin{array}{c}\text { Price } \\
\text { Dispersion } \\
\\
\text { (Big3 Only) }\end{array}$ \\
\hline $\begin{array}{l}\text { \%Book Shopbot } \\
\text { Use }\end{array}$ & $\begin{array}{l}-31.817^{*} \\
(2.817)\end{array}$ & $\begin{array}{l}-5.676^{*} \\
(0.155)\end{array}$ & $\begin{array}{c}-10.758^{*} \\
(1.426)\end{array}$ & $\begin{array}{l}-9.932^{*} \\
(0.294)\end{array}$ \\
\hline $\begin{array}{l}\text { (\%Book Shopbot } \\
\text { Use) }\end{array}$ & - & $\begin{array}{l}9.059^{*} \\
(0.274)\end{array}$ & - & $\begin{array}{l}16.558^{*} \\
(0.504)\end{array}$ \\
\hline Wholesale price & $\begin{array}{l}1.668 * \\
(0.027)\end{array}$ & - & $\begin{array}{l}1.786^{*} \\
(.009)\end{array}$ & - \\
\hline NYT Bestseller & $\begin{array}{l}2.180^{*} \\
(0.240)\end{array}$ & $\begin{array}{l}0.014^{*} \\
(0.002)\end{array}$ & $\begin{array}{l}-1.871^{*} \\
(0.107)\end{array}$ & $\begin{array}{l}-0.011^{*} \\
(0.002)\end{array}$ \\
\hline $\begin{array}{l}\text { Number of Big } 3 \\
\text { Retailers }\end{array}$ & - & - & $\begin{array}{l}-1.130^{*} \\
(0.079)\end{array}$ & $\begin{array}{l}-0.014^{*} \\
(0.001)\end{array}$ \\
\hline $\begin{array}{l}\text { Number of } \\
\text { Retailers }\end{array}$ & $\begin{array}{l}-0.690^{*} \\
(0.029)\end{array}$ & $\begin{array}{l}0.006^{*} \\
(0.000)\end{array}$ & - & - \\
\hline Other binding & $\begin{array}{c}-0.103 \\
(0.353)\end{array}$ & $\begin{array}{l}0.007^{* *} \\
(0.003)\end{array}$ & $\begin{array}{l}0.682^{*} \\
(0.212)\end{array}$ & $\begin{array}{l}0.008^{* *} \\
(0.003)\end{array}$ \\
\hline Hardcover & $\begin{array}{l}-0.036 \\
(0.276)\end{array}$ & $\begin{array}{c}0.002 \\
(0.001)\end{array}$ & $\begin{array}{l}-0.338^{*} \\
(0.097)\end{array}$ & $\begin{array}{l}0.010^{*} \\
(0.001)\end{array}$ \\
\hline Dummies & Categories & Categories & Categories & Categories \\
\hline $\begin{array}{l}\text { Adjusted R- } \\
\text { Square }\end{array}$ & 0.817 & 0.161 & 0.939 & 0.124 \\
\hline $\mathrm{N}$ & 73,096 & 73,096 & 66,734 & 66,734 \\
\hline
\end{tabular}


Table 5. Possible Impact of Bestsellers, Holiday Effect, and Inflation

\begin{tabular}{|c|c|c|c|c|c|}
\hline & $\begin{array}{c}\text { Average } \\
\text { Price } \\
\text { (Excluding } \\
\text { Bestseller) }\end{array}$ & $\begin{array}{l}\text { Dispersion } \\
\text { (Excluding } \\
\text { Bestseller) }\end{array}$ & $\begin{array}{c}\text { Average } \\
\text { Price } \\
\text { (Excluding } \\
\text { Holiday } \\
\text { Season) } \\
\end{array}$ & $\begin{array}{c}\text { Dispersion } \\
\text { (Excluding } \\
\text { Holiday } \\
\text { Season) } \\
\end{array}$ & $\begin{array}{c}\text { Real Average } \\
\text { Price }\end{array}$ \\
\hline $\begin{array}{l}\text { \%Book Shopbot } \\
\text { Use }\end{array}$ & $\begin{array}{l}-30.665^{*} \\
(2.610)\end{array}$ & $\begin{array}{l}-5.390^{*} \\
(0.155)\end{array}$ & $\begin{array}{l}-43.377^{*} \\
(3.668)\end{array}$ & $\begin{array}{l}-4.744^{*} \\
(0.168)\end{array}$ & $\begin{array}{l}-40.697^{*} \\
(2.456)\end{array}$ \\
\hline $\begin{array}{l}\text { (\%Book Shopbot } \\
\text { Use) })^{2}\end{array}$ & - & $\begin{array}{c}8.392^{*} \\
(0.273)\end{array}$ & - & $\begin{array}{c}7.424^{*} \\
(0.316)\end{array}$ & - \\
\hline Wholesale price & $\begin{array}{l}1.672^{*} \\
(0.015)\end{array}$ & - & $\begin{array}{l}1.697^{*} \\
(0.025)\end{array}$ & - & $\begin{array}{l}1.668^{*} \\
(0.015)\end{array}$ \\
\hline NYT Bestseller & - & - & $\begin{array}{l}2.312^{*} \\
(0.256)\end{array}$ & $\begin{array}{c}0.032^{*} \\
(0.002)\end{array}$ & $\begin{array}{l}2.717^{*} \\
(0.255)\end{array}$ \\
\hline $\begin{array}{l}\text { Number of Big } 3 \\
\text { Retailers }\end{array}$ & $\begin{array}{l}-2.009^{*} \\
(0.118)\end{array}$ & $\begin{array}{l}-0.033^{*} \\
(0.001)\end{array}$ & $\begin{array}{l}-2.120^{*} \\
(0.118)\end{array}$ & $\begin{array}{l}-0.029^{*} \\
(0.001)\end{array}$ & $\begin{array}{l}-2.254^{*} \\
(0.112)\end{array}$ \\
\hline $\begin{array}{l}\text { Number of } \\
\text { Retailers }\end{array}$ & $\begin{array}{l}-0.516^{*} \\
(0.024)\end{array}$ & $\begin{array}{c}0.008^{*} \\
(0.000)\end{array}$ & $\begin{array}{l}-0.427^{*} \\
(0.025)\end{array}$ & $\begin{array}{c}0.008^{*} \\
(0.000)\end{array}$ & $\begin{array}{l}-0.507^{*} \\
(0.023)\end{array}$ \\
\hline Other binding & $\begin{array}{l}-0.217 \\
(0.358)\end{array}$ & $\begin{array}{l}0.008^{* *} \\
(0.003)\end{array}$ & $\begin{array}{l}-0.153 \\
(0.338)\end{array}$ & $\begin{array}{l}0.005^{* * *} \\
(0.003)\end{array}$ & $\begin{array}{l}-0.529 \\
(0.344)\end{array}$ \\
\hline Hardcover & $\begin{array}{l}-0.367^{* * *} \\
(0.191)\end{array}$ & $\begin{array}{c}0.008^{*} \\
(0.001)\end{array}$ & $\begin{array}{l}-0.280 \\
(0.259)\end{array}$ & $\begin{array}{c}0.003^{*} \\
(0.001)\end{array}$ & $\begin{array}{l}-0.668^{*} \\
(0.177)\end{array}$ \\
\hline Dummies & Categories & Categories & Categories & Categories & Categories \\
\hline $\begin{array}{l}\text { Adjusted R- } \\
\text { Square }\end{array}$ & 0.797 & 0.161 & 0.127 & 0.198 & 0.776 \\
\hline $\mathrm{N}$ & 69,701 & 69,701 & 71,980 & 71,980 & 75,765 \\
\hline
\end{tabular}

Note: CPI adjusted wholesale price is used in the last column. 
Table 6. All Effects

\begin{tabular}{|c|c|c|}
\hline & $\begin{array}{c}\text { Real_Average } \\
\text { Price }\end{array}$ & $\begin{array}{c}\text { Price } \\
\text { Dispersion }\end{array}$ \\
\hline \%Book Shopbot Use & $\begin{array}{c}-27.009^{*} \\
(3.833)\end{array}$ & $\begin{array}{l}-6.050^{*} \\
(0.216)\end{array}$ \\
\hline$(\% \text { Book Shopbot Use })^{2}$ & - & $\begin{array}{l}9.893^{*} \\
(0.402)\end{array}$ \\
\hline Wholesale price & $\begin{array}{l}1.697^{*} \\
(0.029)\end{array}$ & - \\
\hline NYT Bestseller & - & - \\
\hline $\begin{array}{l}\text { Number of Big } 3 \\
\text { Retailers }\end{array}$ & - & - \\
\hline Number of Retailers & $\begin{array}{l}-0.507^{*} \\
(0.023)\end{array}$ & $\begin{array}{c}0.007^{*} \\
(0.000)\end{array}$ \\
\hline Other binding & $\begin{array}{l}0.652^{* *} \\
(0.317)\end{array}$ & $\begin{array}{c}0.004 \\
(0.003)\end{array}$ \\
\hline Hardcover & $\begin{array}{c}0.330 \\
(0.284)\end{array}$ & $\begin{array}{l}0.002^{* *} \\
(0.001)\end{array}$ \\
\hline Dummies & Categories & Categories \\
\hline Adjusted R-Square & 0.863 & 0.193 \\
\hline $\mathrm{N}$ & 63,494 & 63,494 \\
\hline
\end{tabular}

Note: In Column 1, CPI adjusted wholesale price is used. 
Table 7. Lagged Effects

\begin{tabular}{|c|c|c|}
\hline & Average Price & $\begin{array}{c}\text { Price } \\
\text { Dispersion }\end{array}$ \\
\hline $\begin{array}{l}\text { \%Book Shopbot } \\
\text { Use }\end{array}$ & $\begin{array}{c}-44.558^{*} \\
(2.369)\end{array}$ & $\begin{array}{l}-4.463^{*} \\
(0.194)\end{array}$ \\
\hline $\begin{array}{l}\text { (\%Book Shopbot } \\
\text { Use) })^{2}\end{array}$ & - & $\begin{array}{l}7.371^{*} \\
(0.330)\end{array}$ \\
\hline $\begin{array}{l}\Delta \% \text { Book } \\
\text { Shopbot Use }\end{array}$ & $\begin{array}{l}45.009^{*} \\
(2.993)\end{array}$ & - \\
\hline $\begin{array}{l}L^{4}(\Delta \% \text { Book } \\
\text { Shopbot Use })\end{array}$ & - & $\begin{array}{l}0.083^{*} \\
(0.012)\end{array}$ \\
\hline Wholesale price & $\begin{array}{l}1.688^{*} \\
(0.013)\end{array}$ & - \\
\hline NYT Bestseller & $\begin{array}{l}2.348^{*} \\
(0.255)\end{array}$ & $\begin{array}{c}0.042^{*} \\
(0.001)\end{array}$ \\
\hline $\begin{array}{l}\text { Number of Big } 3 \\
\text { Retailers }\end{array}$ & $\begin{array}{l}-2.929^{*} \\
(0.118)\end{array}$ & $\begin{array}{l}-0.023^{*} \\
(0.001)\end{array}$ \\
\hline $\begin{array}{l}\text { Number of } \\
\text { Retailers }\end{array}$ & $\begin{array}{l}-0.424^{*} \\
(0.023)\end{array}$ & $\begin{array}{l}0.009^{*} \\
(0.000)\end{array}$ \\
\hline Other binding & $\begin{array}{l}-0.559 \\
(0.348)\end{array}$ & $\begin{array}{c}0.003 \\
(0.003)\end{array}$ \\
\hline Hardcover & $\begin{array}{l}-0.704^{*} \\
(0.173)\end{array}$ & $\begin{array}{l}-0.002^{*} \\
(0.001)\end{array}$ \\
\hline Dummies & Categories & Categories \\
\hline $\begin{array}{l}\text { Adjusted R- } \\
\text { Square }\end{array}$ & 0.799 & 0.212 \\
\hline $\mathrm{N}$ & 74,914 & 66,332 \\
\hline
\end{tabular}

Note: CPI adjusted prices and wholesale prices are used. $\Delta$ (\%Book Shopbot Use $)=(\%$ Book Shopbot Use) $)_{t}-(\% \text { Book Shopbot Use })_{t-1}, t$ indicating a month. In $L^{4}(\Delta \%$ Book Shopbot Use), $L$ is the lag operator. 


\section{Figure 1. Sample Dealtime Webpage}

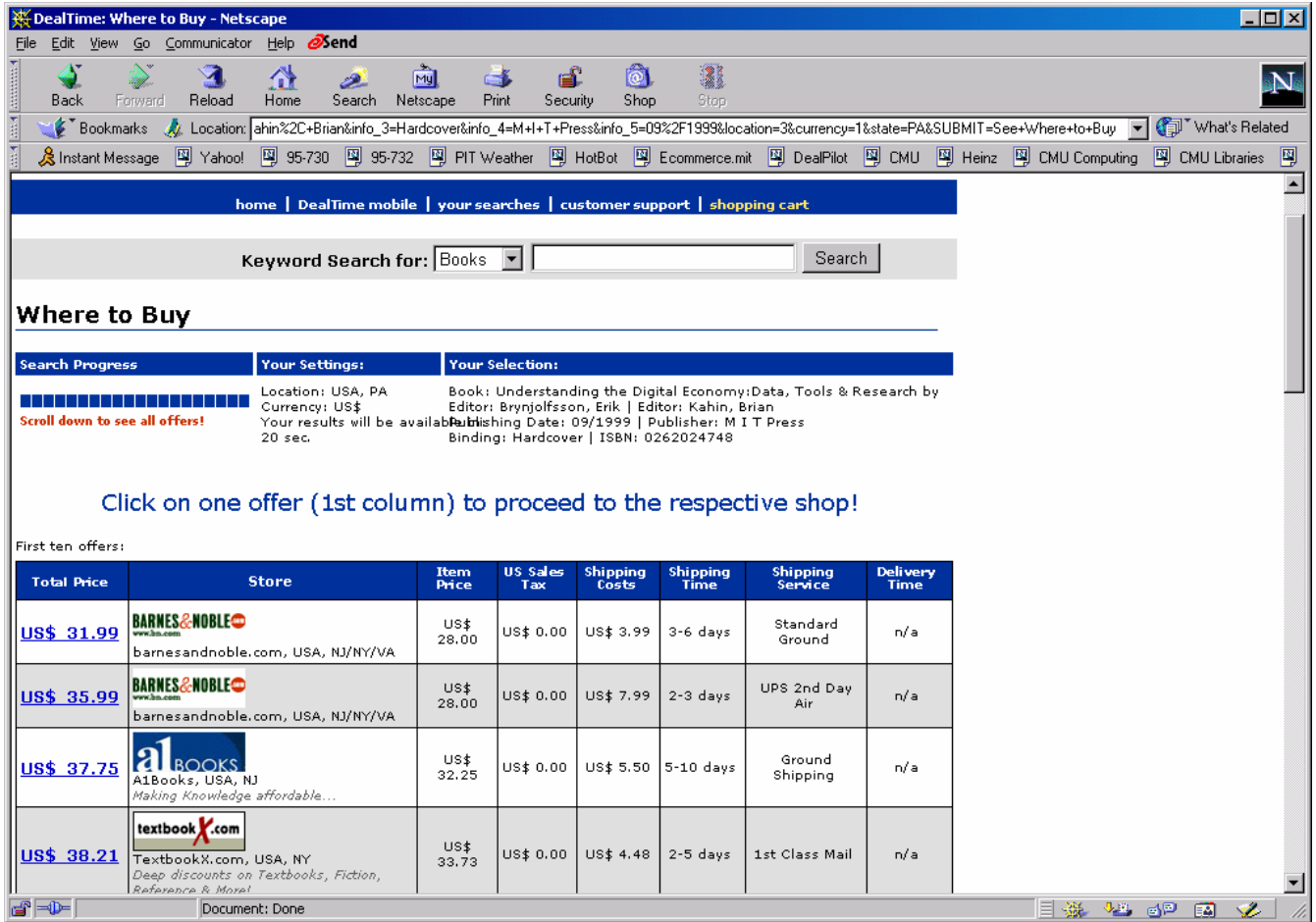


Figure 2. Monthly Change of Shopbot Use

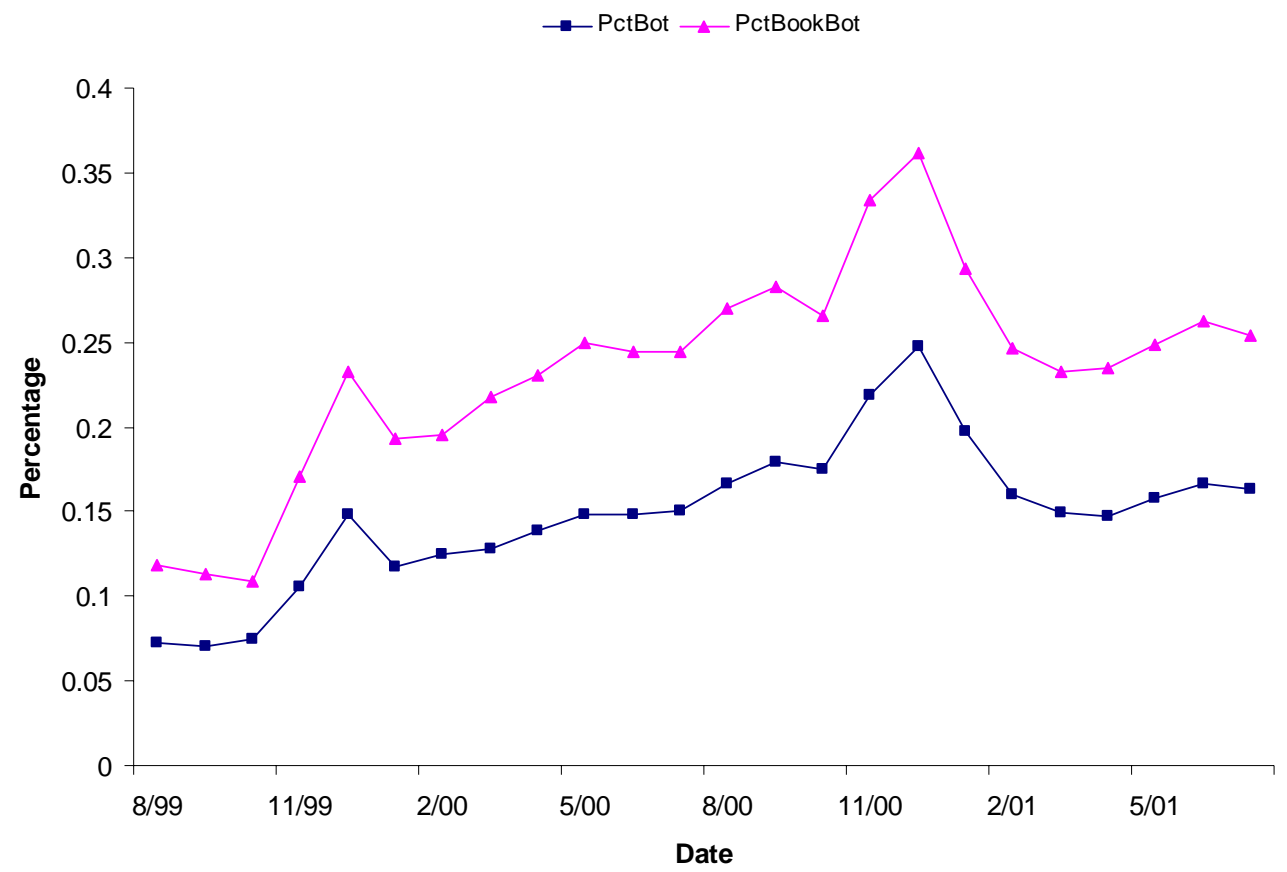

Note: PctBot is the percentage of shopbot use. PctBookBot is the percentage of book shopbot use. 
Figure 3. Nonlinear Effect of Shopbot Use on Price Dispersion

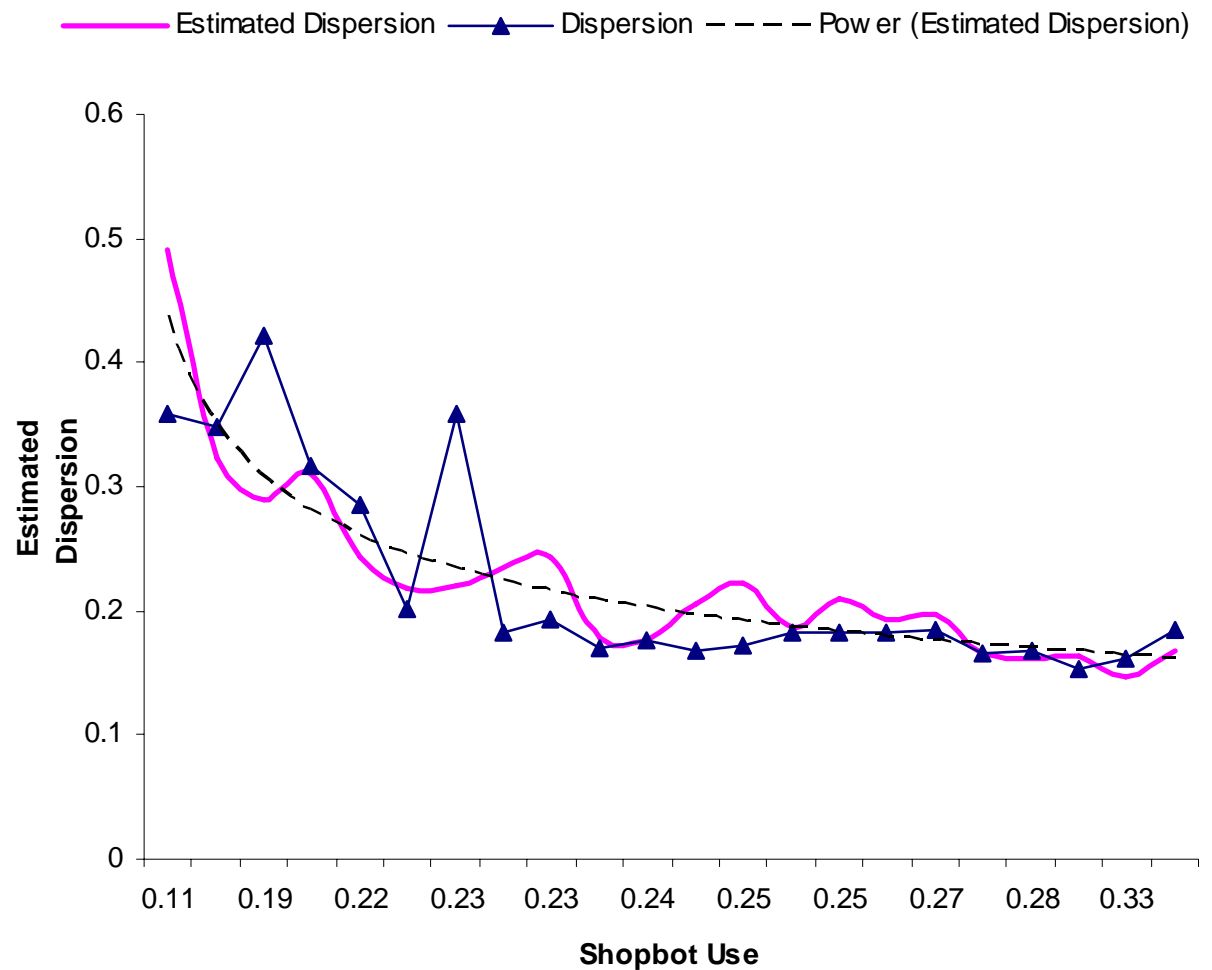

Note: _ _ _ is an approximate trendline using the power function. 
Figure 4. Monthly Change of Price and Price Dispersion
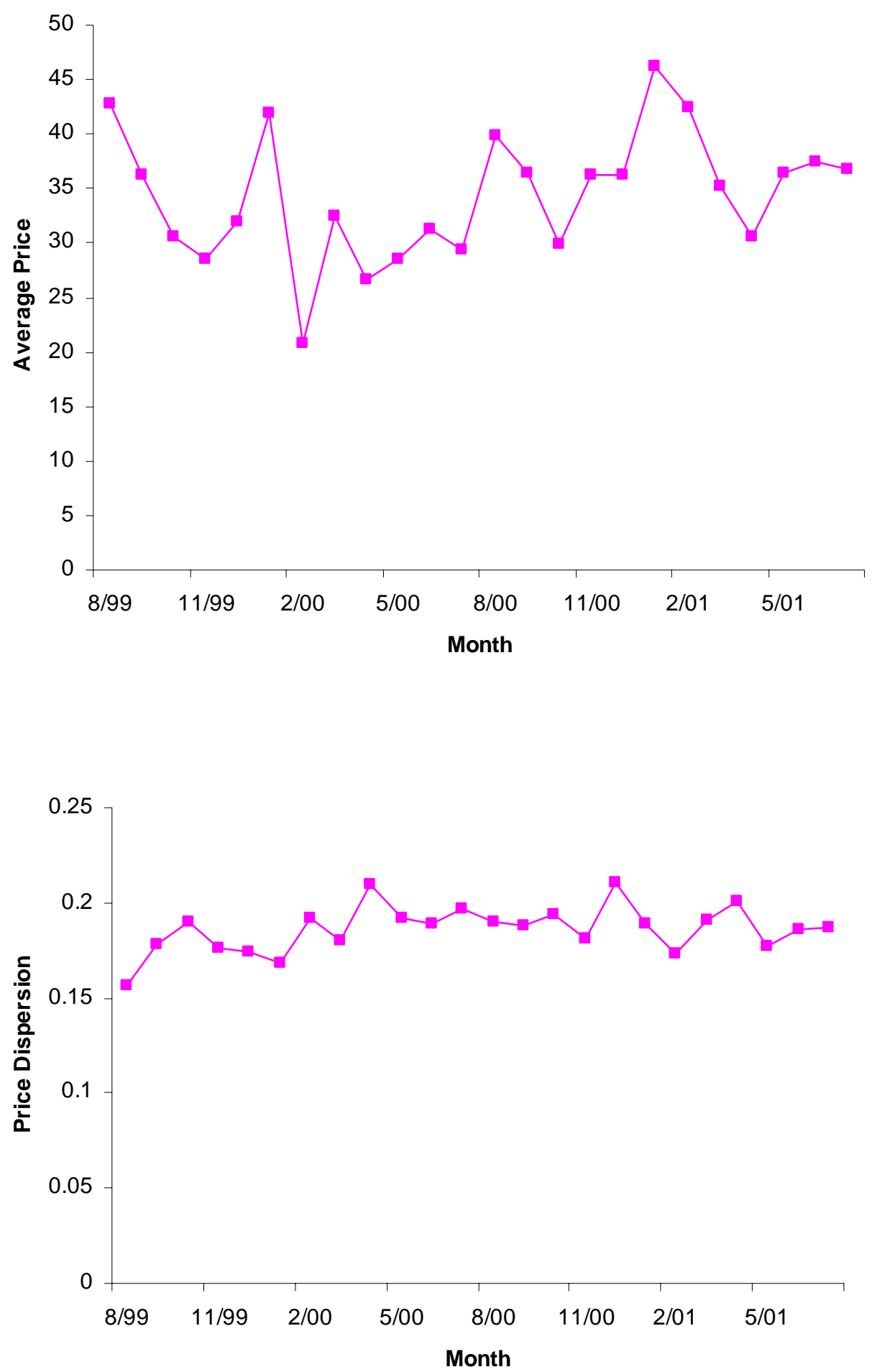